\title{
DOES SLEEP QUALITY SERVE AS A MEDIATOR BETWEEN WELL- BEING AND ACADEMIC ACHIEVEMENT?
}

\author{
Yulia Ayriza*, Farida Agus Setiawati, Siti Rohmah Nurhayati, Sasanty Ratna Gumelar, \\ Eka Putri Desy Rahmawati Sholeha \\ Pascasarjana, Universitas Negeri Yogyakarta \\ *e-mail: yulia_ayriza@uny.ac.id
}

\begin{abstract}
The transition from high school to college "forces" freshmen students to lead a brand new life until they eventually manage to adapt to the new environment and all its activities. Freshmen students who failed to adapt themselves to the environment will face various problems including the degradation of well-being which consequently affects their academic achievement and gets worse when it affects their sleep quality. This expost facto research design aims to examine whether sleep quality serves as a mediator between wellbeing and academic achievement. The participants comprise 231 freshmen students of a public university in Yogyakarta, Indonesia for the academic year 2017. They were collected using multilevel randomization conducted on seven existing University faculties. The data were collected using Positive Affect and Negative Affect Schedule (PANAS), Life Satisfaction, and Pittsburg Sleep Quality Index (PSQI) and were analyzed using multiple regression technique. The results of the analysis demonstrated that sleep quality does not significantly mediate the relationship between well-being and academic achievement of freshmen students. However, this research found that the negative affect which constitutes a component of well-being significantly results in poor sleep quality. Therefore, it is highly recommended to improve well-being through prevention on the development of negative affect on students.
\end{abstract}

Keywords: well-being, mediator, sleep quality, academic achievement

\section{APAKAH KUALITAS TIDUR BERPERAN SEBAGAI MEDIATOR ANTARA WELL-BEING DENGAN PRESTASI AKADEMIK?}

Abstrak: Transisi dari sekolah menengah ke perguruan tinggi "memaksa" para mahasiswa baru untuk menjalani kehidupan yang berbeda dari sebelumnya, hingga akhirnya mampu beradaptasi dengan gaya hidup di lingkungan baru dengan segala aktivitasnya. Mahasiswa baru yang tidak dapat beradaptasi akan mengalami berbagai masalah, antara lain menurunnya well-being, yang kemudian dapat berpengaruh pada prestasi akademiknya dan dapat diperparah apabila menurunnya well-being berpengaruh pula pada kualitas tidurnya. Penelitian expost facto ini bertujuan untuk menguji apakah kualitas tidur berperan sebagai mediator antara well-being dengan prestasi akademik. Partisipan berjumlah 231 mahasiswa baru universitas negeri di Yogyakarta, Indonesia tahun ajaran 2017 yang diperoleh berdasarkan hasil randomisasi bertingkat dari tujuh fakultas yang ada. Data dikumpulkan dengan skala PANAS Positive Affect and Negative Affect Schedule), Life Satisfaction, dan PSQI (Pittsburg Sleep Quality Index) serta dianalisis dengan teknik regresi berganda. Hasil analisis menunjukkan bahwa kualitas tidur tidak secara signifikan memediasi hubungan antara well-being dengan prestasi akademik mahasiswa baru. Meskipun demikian, penelitian ini menemukan bahwa afek negatif) yang merupakan komponen well-being secara signifikan berpengaruh pada kualitas tidur yang buruk. Untuk itu, peningkatan well-being melalui pencegahan dan penekanan terhadap berkembangnya afek negatif pada mahasiswa sangat disarankan.

Kata Kunci: well-being, mediator, kualitas tidur, prestasi akademik 


\section{INTRODUCTION}

Starting a university term can be the dreams of students who have just recently graduated from Senior or Vocational High School. Being admitted to the desired university serves as a motivation for students to enter either private or state universities with a good reputation.

The participated university is one of the highly sought-after state universities in the Yogyakarta province. In 2017, it was recorded that there are 37,000 applicants enrolled in higher education institutions through National Selection to Enter State University (SNMPTN) scheme with the number of admitted students of 1600. This high enthusiasm is reflected in the percentage of accepted applicants, which does not exceed $5 \%$ of the total applicants. With the acceptance rate unproportional to high enthusiasm rate, students tend to feel content for being admitted to the university.

The feeling of content is one of the components in well-being in which a person assesses his life satisfaction level. Seligman (2011) asserts that those who have positive affect ratio higher than the negative affect and feel content with their lives for they have managed to achieve their desired goals and having self-worth shall fall under the classification of people with subjective well-being. This is in congruence with the opinion of Diener, Lucas, \& Oishi (2005) who maintain that subjective well-being is comprised of two basic components, including the evaluation on goal achievement or is often termed as life satisfaction which falls under the category of a cognitive component and positive emotional reaction or is often termed as happiness which falls under the category of an affective component.

As the transition from high school to higher education institutions experiences changes, the well-being of freshmen students is also subject to experiencing changes. If changes as a result of transition encompassing the process of selfadjustment such as social integration, interpersonal relationship, personal wellbeing and emotional balance which serve as the predictors of well-being are not anticipated, they will result in damaging consequences such as academic failure and school drops out (Imaginário, Vieira, \& Jesus, 2013).

In addition to academic achievement, sleep quality is another consequence of well-being as proved by the results of experimental research conducted by Jackowska, Brown, Ronaldson, \& Steptoe (2016) using the intervention of gratitude in a short twoweek period as a form of manipulation of participant's well-being. Their findings discovered that improved well-being correlates with increased sleep quality along with decreasing blood pressure. Thus, students' sleep quality, especially that of the freshmen students, can lead to a poor level if those who are experiencing transition and adaptation have a decline in their well-being.

The findings of Radek \& Kaprelian (2013) and Marques, Meia-Via, da Silva, $\&$ Gomes (2017) revealed that students are inclined to having poor sleep quality which may subsequently lead to a decline in health and psychological wellbeing (Pilcher, Ginter \& Sadowsky, 1997). Poor sleep quality has a significant effect on the quality of life from the aspects of physical, psychological and quality of the environment (Marques et al., 2017). Additionally, it is also explained that sleep quality is found to potentially serve as a contributor to psychopathological symptoms. Gaultney \& Collins-moneil, (2009) found that students with poor sleep quality will eventually have low productivity level. Furthermore, poor sleep quality also has an impact on emotional disorders (Asarnow, McGlinchey, \& Harvey, 2014; Gaultney \& Collins-meneil, 2009), health problems such as depression, fatigue, having a hard time paying attention (ADHD), concentrating, and making decisions (Giannotti, Cortesi, Sebastiani, \& Ottaviano, 2002), as well as 
might trigger academic problems (Sweileh, Ali, Sawalha, Abu-Taha, Zyoud, \& AlJabi, 2011). This can happen because sleep is a healthy rest period in which a nervous system is restored to save energy as well as to restore basic physical condition which is required to perform daily activities (Boeree, 2013). Luyster (2013) also implies that sleep poses a complex physiological process as well as a complex behavior which makes up a part of human life and serves as one of the determinants of physical and mental health. Therefore, it is not surprising that sleep quality can have an effect on an individual's academic performance.

It can be concluded from the aboveexplained findings that well-being has a consequence on the results of students' academic achievement (Imaginário et al., 2013). In the meantime, well-being also has an effect on sleep quality (Jackowska et al., 2016), and sleep quality has an effect on academic achievement (Sweileh et al. 2011). Based on a bivariate relationship among the three variables, this study examined the relationship between wellbeing and academic achievement which is mediated by sleep quality of freshmen students. The findings of this study can shed light on the efforts to maintain or improve the well-being of freshmen students, and maintain health with good sleep quality, in order to achieve satisfactory academic achievement. The hypothesis in this study is that sleep quality serves as a mediator between wellbeing and students' academic achievement.

\section{METHOD}

\section{Participants}

The participants in this study were 231 samples of students aged between 17 to 23 years. The population of our study was semester one students studying at a public university in Yogyakarta, Indonesia. The samples were collected using multistage random sampling technique which means that the samples were collected in random and in multistage according to a certain unit. The first random sampling was conducted at the faculty level, the second random sampling was conducted at the department level, and the last sampling was conducted at the classroom level. The number of samples was determined using Slovin formula by first knowing the total number of population.

\section{Instruments, procedures of data collection and data analysis}

The instruments were completed by the participants at the end of the second semester with first completing inform consents. Completing the instruments in the form of scales during the class session was done by first asking permission from the lecturer of the course.

An instrument of well-being consists of two scales, i.e. Positive Affect and Negative Affect Schedule (PANAS) scale that was proposed by Watson, Clark, \& Tellegan (1988) and Life Satisfaction scale proposed by Diener, Emmons, Larsen, \& Griffin (1985). The PANAS scale consists of two mood scale (20 items) where 10 items measure the positive affect (PA) and the remaining 10 items measure the Negative Affect (NA). PANAS scale presents five alternative answers for each affect. The participants of the research were instructed to choose one of the five alternative answers that show affect intensity level felt at the moment. On the PANAS scale, the score is on a scale of 1 (never) to 5 (always). In the meantime, life satisfaction scale is a 5-item scale designed to measure global cognitive assessment of an individual's life satisfaction (not the size of positive or negative effect). The respondents only need to show the number of question items they agree or disagree with each of the 5 items using a 5 point scale that scores between 1 (never) to 5 (always). While the reliability for the scale of positive affect ranged from $0,86-0,90$; the reliability for the scale of negative affect ranged from 
0.84 to 0.87 (Watson et al., 1988); and the reliability for the scale of life satisfaction is 0.87 ( Diener et al., 1985).

The instrument used to measure the scale of sleep quality was adapted from the PSQI instrument (Pittsburg Sleep Quality Index) developed by Buysse, Reynolds, Monk, Berman \& Kupfer (1988) with the reliability of 0,83 . The instrument consists of 7 components of sleep quality, including subjective sleep quality, sleep latency, sleep duration, habitual sleep efficiency, sleep disorders at night (sleep disturbance), use of drugs to help fall sleep (sleep medication) and sleep disorders frequently experienced at night (daytime disfunction). The instruments were selfcompleted by the participant based on their sleep experiences and are presented on a scale of 1 to 4 . The higher the total points obtained from the participants, the worse their sleep quality accordingly.

The first-semester grade point average was used to measure academic achievement. The grade point average was obtained from the results of the assessment on academic achievement for one semester or approximately six months in the first semester of the class with various core courses.

The collected and analyzed data were quantitatively analyzed by describing well-being, sleep quality and academic achievement of students based on its tendency of centrality; while the analysis of hypothesis testing was performed using path analysis with the help of SPSS program. For the purpose of hypothesis testing, there are three variables involved in this research, viz. well-being as an independent variable, sleep quality as a mediator variable, and academic achievement as a dependent variable.

\section{RESULTS AND DISCUSSION}

\section{Results}

Table 1 shows the average, maximum score, minimum score and standard deviation on each variable. The scores of positive affect range from 16-50, negative affect range from 11-42, life satisfaction range from 6-23, well-being range from 11-53, sleep quality ranges from 9-24, and academic achievement ranges from 2,4-3,9.

Table 1. Descriptive Statistics of Research Data

\begin{tabular}{lcccccc}
\hline \multicolumn{1}{c}{ Statistics } & $\begin{array}{c}\text { Positive } \\
\text { Affect }\end{array}$ & $\begin{array}{c}\text { Negative } \\
\text { Affect }\end{array}$ & $\begin{array}{c}\text { Life } \\
\text { Satisfaction }\end{array}$ & Well-being & $\begin{array}{c}\text { Sleep } \\
\text { Quality }\end{array}$ & $\begin{array}{c}\text { Academic } \\
\text { Achievement }\end{array}$ \\
\hline Mean & 34.0 & 25.4 & 15.5 & 24.5 & 15.4 & 3.4 \\
Std. Deviation & 6,343 & 6,325 & 3.1648 & 11.2883 & 2.960 & .2706 \\
Minimum & 16.0 & 11.0 & 6.0 & -11.0 & 9.0 & 2.4 \\
Maximum & 50.0 & 42.0 & 23.0 & 53.0 & 24.0 & 3.9 \\
\hline
\end{tabular}

Furthermore, when interpreted into a 5 scale category (presented in Appendix), based on the value of the average score (Table 1), the following results were obtained : (1) with the average score of positive affect of 34 , then the positive affect of the university freshmen students is categorized into a moderate level; (2) with the average score of negative affect of 25.4, the negative affect of the university freshmen students is categorized into a low level; (3) with the average score of life satisfaction of 15.5, then the university freshmen students' life satisfaction is categorized into a a moderate level; (4) with the average score of well-being of 24.5 , then the well-being of the university freshmen students is categorized into a moderate level; (5) with the average score of sleep quality of 15.4; then the sleep quality of the university freshmen students is categorized into a very high level; and (6) with the average score of academic achievement of 3.4 ; then the academic 
achievements of the university freshmen students are categorized into a very satisfactory level.

Table 2 presents score distribution on each variable. Table 2 above shows that students' positive affect is predominantly at the category of moderate level by $39 \%$, while students' negative affect is predominantly at the category of low level by $43 \%$. Life satisfaction and well-being of freshmen students is predominantly at the category of moderate level by between $52 \%$ and 53\%, while students' sleep quality is predominantly at the category of very high by $54 \%$.

Table 3. Presents data distribution on students' academic achievement by Grade Point Average, with the majority of students gained a very satisfactory $(49 \%)$ academic achievement.

The results of path analysis presented in Figure 1 shows that path a $\left(\beta_{\mathrm{a}}\right.$
$=-0,237)$ between the effect of well-being on sleep quality obtained significant results $(\mathrm{p}<0.05)$, which indicates that well-being has a significant effect on sleep quality. The negative path (-) on line a indicates that the more negative the students' well-being, the higher the rate of students' sleep quality which thus translates into worsened sleep quality. Path $b\left(\beta_{b}=0,060\right)$ between sleep quality and academic achievement revealed insignificant results $(\mathrm{p}>0.05)$, which means that sleep quality has no significant effect on students' academic achievement. Path $c^{\prime}\left(\beta_{c^{\prime}}=-0,003\right)$ where the relationship between well-being and academic achievement mediated by sleep quality revealed insignificant results $(\mathrm{p}=0,969$ or $\mathrm{p}>0.05)$, thus, it can be inferred that sleep quality does not serve as a mediator between well-being and academic achievement.

Table 2. Respondents Distribution by Positive Affect and Negative Affect Life Satisfaction, Well-Being, and Sleep Quality

\begin{tabular}{lccccc}
\hline Category & \multicolumn{5}{c}{ Number of Respondents (\%) } \\
\cline { 2 - 6 } & $\begin{array}{c}\text { Positive Affect } \\
\text { Score (\%) }\end{array}$ & $\begin{array}{c}\text { Negative } \\
\text { Affect } \\
\text { Score (\%) }\end{array}$ & $\begin{array}{c}\text { Life } \\
\text { Satisfaction } \\
\text { Score (\%) }\end{array}$ & $\begin{array}{c}\text { Well-being } \\
\text { Score (\%) }\end{array}$ & $\begin{array}{c}\text { Sleep Quality } \\
\text { Score (\%) }\end{array}$ \\
\hline Very High & $26(11)$ & $0(0)$ & $8(3)$ & $10(4)$ & $125(54)$ \\
High & $86(37)$ & $20(9)$ & $49(21)$ & $86(37)$ & $104(45)$ \\
Moderate & $91(39)$ & $78(34)$ & $120(52)$ & $123(53)$ & $2(1)$ \\
Low & $26(11)$ & $99(43)$ & $47(20)$ & $12(5)$ & $0(0)$ \\
Very Low & $2(1)$ & $34(15)$ & $7(3)$ & $0(0)$ & $0(0)$ \\
\hline
\end{tabular}

Table 3. Respondents Distribution by Academic Achievement

\begin{tabular}{lc}
\hline \multicolumn{1}{c}{ Category of Academic Achievement } & Number of Respondents (\%) \\
\hline Excellent & $96(42)$ \\
Very Good & $114(49)$ \\
Good & $19(8)$ \\
Satisfactory & $2(1)$ \\
Unsatisfactory & $0(0)$ \\
\hline
\end{tabular}

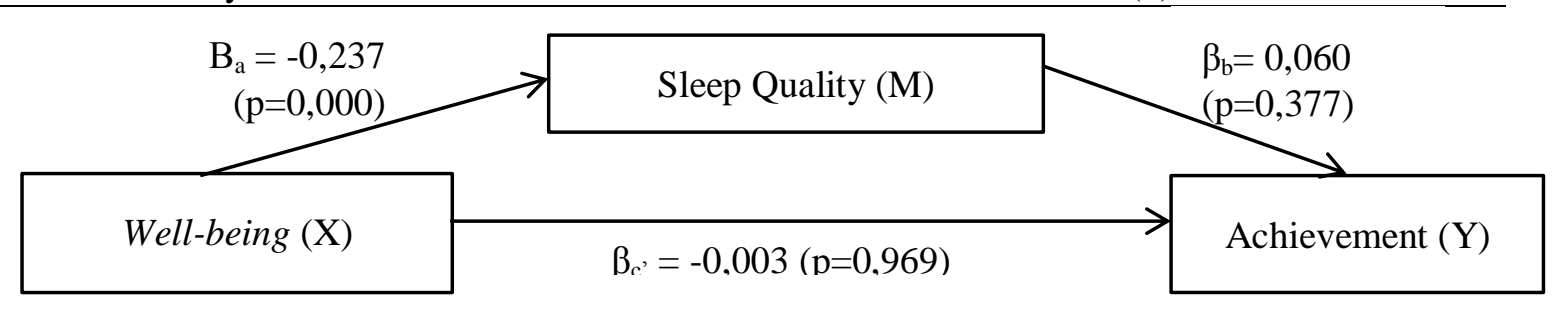

Figure 1. Hypothesis Path Diagram 


\section{Discussions}

Based on our findings, it was discovered that the freshmen students' positive affect falls under the category of moderate level, while negative affect falls under the category of low level. With the positive affect higher than the negative affect, it shows us that the person leads a good life (Anas \& Akhouri, 2013; Zanon, Bastianello, Pacico, \& Hutz, 2013). Students with high positive affect and low negative affect are signified by high energy, low emotionality, full concentration and a sense of high optimism (Hu \& Gruber, 2008).

Life satisfaction and well-being of new students on average fall under the category of moderate level. This can be explained from the opinions of Shin \& Johnson (1978), and Veenhoven (1996) who maintain that life satisfaction leads to a person's well-being and happiness during his life. This is because a person's well-being is dependent upon how a person responds to the life quality he leads and how he evaluates his life in a positive way, both on a cognitive and emotional assessment (Diener et al., 1985; Tov, 2018). The feeling of life satisfaction in students will generate greater endurance and stronger resilience in facing academic challenges at the university (Rode, Arthaud-Day, Mooney, Near, Baldwin, Bommer, \& Rubin, 2005).

Our findings further demonstrate that students' sleep quality falls under the category of very high despite the fact that students are known with their uncertain sleeping schedule or late sleep hours (Orzech, Salafsky, \& Hamilton, 2011). This high freshmen students' sleep quality can be explained by the findings of Marks \& Landaira (2015) and Robotham, Chakkalackal, \& Cyhlarova (2011) which revealed that there is no specific sleep duration setting suitable for everyone because some people may need more sleep hours than the others (depending on a person's psychological and physiological state); including how, when and where people choose to sleep, in addition to cultural traditions and related customs(Early Head Start National Resource Center, 2009). Therefore, irrespective that students have short sleep hours, it does not necessarily mean that their sleep quality is consistently not good. Nevertheless, this high sleep quality is highly beneficial for students as sleep is able to maintain physical health, cognition, and emotional state of a person (Abraham, $\mathrm{Pu}$, Schleiden, \& Albert, 2017).

On the path analysis results, it was found that sleep quality does not serve as a mediator between well-being and academic achievement. This is because only the path of the effect of well-being on sleep quality proved to be significant, while other paths, either well-being on academic achievement or sleep quality on academic achievement proved insignificant. Baron dan Kenny (1986) point out that the role of a mediator can function only when the path that connects the independent variables with a mediating variable, a mediating variable with dependent variables and independent variables with dependent variables is proved to have significant effects. For more specific results, the findings of this study will be elaborated on each path. Before the final part, we will discuss the overall relationship model.

First, analysis results of path a between well-being and sleep quality proved to be significant. This illustrates that people with good wellbeing will have good quality sleep. This finding is in line with the results of experimental research conducted by Jackowska et al., (2016) who examined the effect of gratitude intervention of well-being on sleep quality and health. Their findings showed that with an increase in positive emotion, participants' good sleep quality will accordingly increase, and a decline in negative emotion will reduce sleep disorders globally.

Secondly, on path b, viz. the relationship between sleep quality and 
academic achievement proved to be insignificant. This is because, during data collection, the sleep quality performed failed to follow the original plan, in which students were still in the transition phase of adjusting to new campus life at an early semester. This is because of the delayed acceptance of our research proposal (four months approval as of the date of the end of first semester), which causes a long time lapse of less than four months between the time of collecting sleep quality data and the time of collecting academic achievement data. The time bias of collecting the data between both variables highly likely affects the results of our research. As such, the results of research on path $b$ is conflicting to the results of the previous research which found that sleep quality has an effect on students' academic achievement (Radek \& Kaprelian, 2013), therefore conducting similar research by taking account of the conformity of the time of data collection between the two variables under study is highly recommended.

Third, path c which connects wellbeing with academic achievement has also proven to be insignificant. Similarly, the relationship between sleep quality and academic achievement, the long time lapse of data collection between the variable of well-being and academic achievement can potentially influence the outcome of this research. However, the negative affect which constitutes one of the components of well-being has a significant impact on the students' sleep quality $\left(\beta_{\mathrm{a}}=0,305\right.$, with $\mathrm{p}=0,000$ or $\mathrm{p}<0.05)$, while other components, such as the effect of positive affect on sleep quality $\left(\beta_{\mathrm{a}}=-0,055\right.$ with $\mathrm{p}$ $=0,406$ or $p>0.05)$ and the effect of life satisfaction on sleep quality $\left(\beta_{\mathrm{a}}=-0,127(\mathrm{p}\right.$ $=0,053$ or $\mathrm{p}>0.05)$ proved to be insignificant. This finding is interesting by itself because it indicates that when the university freshmen students experience negative affect, their sleep quality will be affected. This is in line with the findings of Jackowska et al., (2016) which found that negative emotion has an effect on sleep disorders globally. On the other hand, the positive affect and life satisfaction of the university students do not really affect their sleep quality. This can be interpreted in a situation when they are happy, they take it for granted and are nonchalant which subsequently has no effect on their sleep quality, on the contrary when students experience negative affect, they feel it and are conscious about it which affect their sleep quality. This background of study can be further examined with a qualitative approach.

Finally, the unproven relationship of sleep quality as a mediator between wellbeing and academic achievement in addition to being caused by technical problems that resulted in path $\mathrm{b}$ and path $\mathrm{c}$ insignificant (Picture 1), also caused by other factors that play a more dominant role in mediating the relationship between well-being and students' academic achievement. Those factors include the involvement and support of parents in every process of education, a positive relationship between students and teachers and their peers (Kindekens, Reina, Backer, Peeters, Buffel, \& Lombaerts, 2014), social intelligence and cognitive factors in the students themselves (Wulanyani \& Vembriati, 2018), self-regulated learning ability that hones students to increase independence in completing tasks and solving problems (Kaplan \& Maehr, 1999; Noble et al., 2008), a supportive and caring educational community (Cowen, 2000; Engels, Aelterman, van Petegem, \& Schepens, 2004; Noble et al., 2008), as well as a psychologically and emotionally safe environment and cultivating prosocial values at an early age (Engels, Aelterman, Van Petegem, \& Schepens, 2004; Noble et al., 2008). Therefore, further research can be conducted with more dominant mediators.

\section{CONCLUSION}

Our findings indicate that sleep quality does not serve as a significant mediator of the relationship between well- 
being and academic achievement of freshmen students. This is because sleep quality was found to have no significant effect on academic achievement, similarly, well-being was found to have no significant effect on students' academic achievement. Nonetheless, the present research discovered that well-being significantly affects students' sleep quality; the components of well-being that support the effect significance is merely comprised of negative affect sub-variable, while other two sub-variables, such as positive affect and life satisfaction do not support the significance of the effect of well-being on sleep quality. This can be interpreted that during the experience of negative affect, students' sleep quality is affected significantly and that means that their sleep quality can potentially decrease. While during the experience of positive affect and life satisfaction, the students are not aware of it and thus does not affect their sleep quality or in other words, their sleep quality has not improved.

The outcomes of this research suggest that, as well-being has a significant effect on students' sleep quality, an improvement shall be made on well-being, especially through prevention and emphasis in negative affect experienced by students, so that students' sleep quality can be adequately maintained. This is important because sleep quality can have an effect on physical and psychological health of students, in that students' daily life activities can be efficiently performed.

\section{ACKNOWLEDGMENT}

Our gratitude are due to the participated university through the Graduate School for funding this research, faculty members who assisted the data collection as well as those who have provided tremendous help in this research.

\section{REFERENCES}

Abraham, O., Pu, J., Schleiden, L. J., \&
Albert, S. M. (2017). Factors contributing to poor satisfaction with sleep and healthcare seeking behavior in older adults. Sleep Health, 3(1), 43-48. doi: 10.1016/j.sleh.2016.11.004.

Anas, M., \& Akhouri, D. (2013). Positive and negative affect in depressed and normal adults. Aging, Neuropsychology, and Cognition: A Journal on Normal and Dysfunctional Development, 20(5), 532-552. doi: 10.1080/13825585.2012.747671.

Asarnow, L. D., McGlinchey, E., \& Harvey, A. G. (2014). The effects of bedtime and sleep duration on academic and emotional outcomes in a nationally representative sample of adolescents. Journal of Adolescent Health, 54(3), 350-356. doi: 10.1016/j.jadohealth.2013.09.004.

Baron, R. M., \& Kenny, D. A. (1986). The moderator-mediator variable distinction in social psychological research: Conceptual, strategic, and statistical considerations. Journal of Personality and Social Psychology, 51(6), 1173-1182. doi: 10.1037/0022-3514.51.6.1173.

Boeree, C. G. (2013). General psychology: Psikologi kepribadian, persepsi, kognisi, emosi, dan perilaku. Yogyakarta: Primasophie.

Buysse, D. J., Reynolds, C. F. 3Rd, Monk, T. H., Berman, S. R., \& Kupfer, D. J. (1988). The pittsburgh sleep quality index: A new instrument for psychiatric practice and research. Psychiatry Res. doi: 10.1016/01651781(89)90047-4.

Cowen, E. L. (2000). Community psychology and routes to psychological wellness. In J. Rappaport \& E. Seidman (Eds.), Handbook of Community 
Psychology (pp. 79-99). Boston, MA: Springer US. doi: 10.1007/9781-4615-4193-6_4.

Diener, E., Emmons, R. A., Larsen, R. J., \& Griffin, S. (1985). The satisfaction with life scale. Journal of Personality Assessment, 49(1), 71-75. doi: 10.1207/s15327752jpa4901_13.

Diener, E., Lucas, R. E., \& Oishi, S. (2005). Subjective well-being: The science of happiness and life satisfaction. In C. R. Snyder \& S. J. Lopez (Eds.), Handbook of positive psychology (2nd ed., pp. 63-73). New York, NY: Oxford University Press. doi:

10.1093/oxfordhb/9780195187243.01 3.0017 .

Early Head Start National Resource Center. (2009). The culture of sleep and child care. Media. PA: Early Head Start National Resource Center.

Engels, N., Aelterman, A., Van Petegem, K., \& Schepens, A. (2004). Factors which influence the well-being of pupils in Flemish secondary schools. Educational Studies, 30(2), 127-143. doi: 10.1080/0305569032000159787.

Gaultney, J. F., \& Collins-mcneil, J. (2009). Lack of sleep in the workplace: What the psychologistmanager should know about sleep, 12(2), 132-148. doi: $10.1080 / 10887150902905454$.

Giannotti, F., Cortesi, F., Sebastiani, T., \& Ottaviano, S. (2002). Circadian preference, sleep and daytime behaviour in adolescence. Journal of Sleep Research, 11(3), 191-199. doi: 10.1046/j.1365-2869.2002.00302.x.

Hu, J., \& Gruber, K. J. (2008). Positive and negative affect and health functioning indicators among older adults with chronic illnesses. Issues in Mental Health Nursing, 29(8), 895911.
10.1080/01612840802182938.

Imaginário, S., Sérgio Vieira, L., \& Neves De Jesus, S. (2013). Subjective wellbeing and social integrationof college students. Journal of Spatial and Organizational Dynamics, 1(3), 215-223.

Jackowska, M., Brown, J., Ronaldson, A., \& Steptoe, A. (2016). The impact of a brief gratitude intervention on subjective well-being, biology and sleep. Journal of Health Psychology, 21(10), 2207-2217. doi: $10.1177 / 1359105315572455$.

Kaplan, A., \& Maehr, M. L. (1999). Achievement goals and student wellbeing. Contemporary Educational Psychology, 24(4), 330-358. doi: 10.1006/ceps.1999.0993.

Kindekens, A., Reina, V. R., De Backer, F., Peeters, J., Buffel, T., \& Lombaerts, K. (2014). Enhancing Student Wellbeing in Secondary Education by Combining Selfregulated Learning and Arts Education. Procedia - Social and Behavioral Sciences, 116(2014), 1982-1987. doi: 10.1016/j.sbspro.2014.01.507.

Luyster, F. S. (2013). Sleep and health. In M. D. Gellman \& R. J. Turner (Eds.), Encyclopedia of behavioral medicine (pp. 1799-1802). New York Heidelberg Dordrecht London: Springer. doi: 10.1007/978-1-44191005-9.

Marks, R., \& Landaira, M. (2015). Sleep , Disturbances of sleep, stress and obesity: A narrative review. Journal of Obesity \& Eating Disorders, 1(2), 1-6. doi: $10.21767 / 2471-$ 8203.100006 .

Marques, D. R., Meia-Via, A. M. S., da Silva, C. F., \& Gomes, A. A. (2017). Associations between sleep quality and domains of quality of life in a 
non-clinical sample: results from higher education students. Sleep Health, 3(5), 348-356. doi: 10.1016/j.sleh.2017.07.004.

Noble, T., McGrath, H., Wyatt, T., Carbines, R., Robb, L., \& International, E. (2008). Scoping study into approaches to student wellbeing: Final Report. Brisbane, Qld: Australian Catholic University and Erebus International.

Orzech, K. M., Salafsky, D. B., \& Hamilton, L. A. (2011). The state of sleep among college students at a large public University. Journal of American College Health, 59(7), 612-619. doi: 10.1080/07448481.2010.520051.

Pilcher, J. J., Ginter, D. R., \& Sadowsky, B. (1997). Sleep quality versus sleep quantity: Relationships between sleep and measures of health, well-being and sleepiness in college students. Journal of Psychosomatic Research, 42(6), 583-596. doi: 10.1016/S00223999(97)00004-4.

Radek, K. S., \& Kaprelian, J. (2013). Sleep disorders \& therapy emerging adult sleep quality: health and academic performance factors of assessment, 2(2). doi: 10.4172/21670277.1000112.

Robotham, D., Chakkalackal, L., \& Cyhlarova, E. (2011). Sleep stters The impact of sleep on health and wellbeing Mental Health Awareness Week 2011. doi: 978-1-906162-65-8.

Rode, J. C., Arthaud-Day, M. L., Mooney, C. H., Near, J. P., Baldwin, T. T., Bommer, W. H., \& Rubin, R. S. (2005). Life satisfaction and student performance. Academy of Management Learning and Education, 4(4), 421-433. doi: 10.5465/AMLE.2005.19086784. understanding of happiness and wellbeing: The practical guide to using positive psychology to make you happier and healthier. Boston, MA: Nicholas Brealey Publishing.

Shin, D. C., \& Johnson, D. M. (1978). Avowed happiness as an overall assessment of the quality of life. Social Indicators Research, 5(1-4), 475-492. doi: 10.1007/BF00352944.

Sweileh, W. M., Ali, I. A., Sawalha, A. F., Abu-Taha, A. S., Zyoud, S. H., \& AlJabi, S. W. (2011). Sleep habits and sleep problems among Palestinian students. Child and Adolescent Psychiatry and Mental Health, 5(25), 1-8. doi: 10.1186/1753-2000-5-25.

Tov, B. W. (2018). Well-being concepts and components. In E. Diener, S. Oishi, \& L. Tay (Eds.), Handbook of well-being. Salt Lake City, UT: DEF Publishers.

Veenhoven, R. (1996). The study of life satisfaction. In: W. E. Saris, W.E., R. Veenhoven, A. C. Scherpenzeel \& B. Bunting (Eds.), A comparative study of satisfaction with life in Europe (pp. 11-48). Hungary: Eötvös University Press. doi: 10.1016/01620134(91)84505-4.

Watson, D., A. Clark, L., \& Tellegen, A. (1988). Development and validation of brief measures of positive and negative affect: The PANAS scales. Journal of personality and social psychology, 54(6), 1063-1070. doi: 10.1037//0022-3514.54.6.1063.

Wulanyani, N. M. S., \& Vembriati, N. (2018). What factors influence wellbeing of students on performing small group discussion? 2nd International Joint Conference on Science and Technology (Ijcst) 2017, 953, 13-18. doi: $10.1088 / 1742-$ 6596/953/1/012004.

Seligman, M. (2011). Flourish: A new 
Zanon, C., Bastianello, M. R., Pacico, J.

personality in a Brazilian sample. C., \& Hutz, C. S. (2013). Relationships between positive and Paideia, 23(56), 285-292. doi: negative affect and the five factors of

\section{APPENDIX}

Table 1. Categorization of the Positive Affect

\begin{tabular}{lc}
\hline \multicolumn{1}{c}{ Category of Positive Affect } & Criteria \\
\hline Very High & Positive Affect $>42$ \\
High & $34<$ Positive Affect $\leq 42$ \\
Moderate & $26<$ Positive Affect $\leq 34$ \\
Low & $18<$ Positive Affect $\leq 26$ \\
Very Low & Positive Affect $\leq 18$ \\
\hline
\end{tabular}

Table 2. Categorisation of the Negative Affect

\begin{tabular}{lc}
\hline \multicolumn{1}{c}{ Category of Negative Affect } & Criteria \\
\hline Very High & Negative Affect $>42$ \\
High & $34<$ Negative Affect $\leq 42$ \\
Moderate & $26<$ Negative Affect $\leq 34$ \\
Low & $18<$ Negative Affect $\leq 26$ \\
Very Low & Negative Affect $\leq 18$ \\
\hline
\end{tabular}

Table 3. Categorization of the Life Satisfaction

\begin{tabular}{lc}
\hline \multicolumn{1}{c}{ Category of Life Satisfaction } & Criteria \\
\hline Very High & Life satisfaction $>21$ \\
High & $17<$ Life Satisfaction $\leq 21$ \\
Moderate & $13<$ Life Satisfaction $\leq 17$ \\
Low & $9<$ Life Satisfaction $\leq 13$ \\
Very Low & Life Satisfaction $\leq 9$ \\
\hline
\end{tabular}

Table 4. Categorization of well-being

\begin{tabular}{lc}
\hline \multicolumn{1}{c}{ Category of Well-Being } & Criteria \\
\hline Very High & Well being $>45$ \\
High & $25<$ Well being $\leq 45$ \\
Moderate & $5<$ Well being $\leq 25$ \\
Low & $-15<$ Well being $\leq 5$ \\
Very Low & Well being $\leq-15$ \\
\hline
\end{tabular}

Table 5. Categorization of Sleep Quality

\begin{tabular}{lc}
\hline \multicolumn{1}{c}{ Category of Sleep Quality } & Criteria \\
\hline Very High & Sleep quality $\leq 15.4$ \\
High & $15.4<$ sleep quality $\leq 23.8$ \\
Moderate & $23.8<$ sleep quality $\leq 32,2$ \\
Low & $32,2<$ sleep quality $\leq 40.6$ \\
Very Low & Sleep quality $>40.6$ \\
\hline
\end{tabular}


Table 6. Categorization of Academic Achievement

\begin{tabular}{lc}
\hline \multicolumn{1}{c}{ Category of Academic Achievement } & Criteria \\
\hline Excellent & Academic achievement $>3,50$ \\
Very Good & $3.00<$ academic achievement $\leq 3,50$ \\
Good & $2.76<$ academic achievement $\leq 3,00$ \\
Satisfactory & $2.00<$ academic achievement $\leq 2,76$ \\
Unsatisfactory & Academic achievement $\leq 2.00$ \\
\hline
\end{tabular}

